\title{
Thermoregulatory and productive-related comparisons between wild type and slick- haired Puerto Rican Holstein cows ${ }^{1,2}$
}

\author{
Héctor L. Sánchez-Rodríguez ${ }^{3}$ \\ J. Agric. Univ. P.R. 103(1):69-86 (2019)
}

\begin{abstract}
Anecdotally, wild type (WT) Puerto Rican Holstein cows perform poorly in hot weather compared with their short-haired (SLICK) counterparts, but scientific evidence supporting this claim is limited. Thus, comparisons of their vaginal temperature (VT), sweat gland size (SGS) and milk production (MP) values were made. Data were analyzed by Proc GLIMMIX and REG (SAS). During the cool season (March 2014) VT was similar in WT and SLICK cows $\left(38.71 \pm 0.09\right.$ and $38.71 \pm 0.08{ }^{\circ} \mathrm{C}$, respectively; $\left.\mathrm{P}=0.9634\right)$. However, in the intermediate air temperatures (AT) season (April 2014), WT cows presented VT values $0.25^{\circ} \mathrm{C}$ higher than their SLICK counterparts from 1900-2100h $(P=0.0213)$. Moreover, in the hot season (August 2015) VT was greater in WT than in SLICK cows by $0.31^{\circ} \mathrm{C}$ from $1800-0700 \mathrm{~h}$ and $0900-1600 \mathrm{~h}(P=0.0032)$, and by $0.20^{\circ} \mathrm{C}$ at $0800 \mathrm{~h}(\mathrm{P}=0.0584)$ and $1700 \mathrm{~h}(\mathrm{P}=0.0619)$. The VT increased linearly until AT reached $30.5^{\circ} \mathrm{C}$ in both WT $\left(0.10^{\circ} \mathrm{C}\right.$ per $1^{\circ} \mathrm{C}$ of $\left.\mathrm{AT} ; \mathrm{P}<0.0001\right)$ and SLICK cows $\left(0.08^{\circ} \mathrm{C}\right.$ per $1^{\circ} \mathrm{C}$ of AT; P<0.0001). After $30.5^{\circ} \mathrm{C}$, no further VT-AT relationship was observed. The WT had smaller SGS $(232 \pm 12$ vs. $315 \pm 9$ $\mu \mathrm{m}$ perimeter; $\mathrm{P}=0.0024)$ and smaller MP $(17.11 \pm 0.63 \mathrm{vs}$. $20.26 \pm 1.28 \mathrm{~kg} / \mathrm{d}$; $P=0.0288$ ) than the SLICK cows. The SLICK cows demonstrated superior thermoregulatory capacity, which seems to depend directly on the severity of the AT.
\end{abstract}

Key words: Puerto Rican slick-haired Holstein cow, thermoregulation, heat stress

${ }^{1}$ Manuscript submitted to Editorial Board 21 September 2018.

${ }^{2}$ The author acknowledges the USDA National Institute of Food and Agriculture, Hatch initiative (Project $\mathrm{H}-452$ ) for providing the economic support for this work. The assistance in data collection of Amneris Castro-Ramos, Zully Contreras-Correa, Gladycia Muñiz-Colón, Viviana Colón-González, Jessica Muñiz-Cruz, Jhoan Santiago-Rodríguez, Stacey Ruiz-Ríos, Gabriela Soriano-Varela, Nashaly Cortés-Viruet, Ángel Jiménez-Arroyo and Glorianne Jiménez-Arroyo is highly appreciated. The author also expresses his gratitude to the staff of the Laboratorio de Investigaciones Pesqueras, Departamento de Recursos Naturales y Ambientales in Cabo Rojo, Puerto Rico (Noemí Peña-Alvarado and Wilfredo Torres-Ruiz) for their assistance in preparing the microscopic slides and to José Almodóvar-Rivera (University of Puerto Rico at Mayagüez Campus, Department of Biology) for his assistance in the microscopic analysis.

${ }^{3}$ Associate Professor, Animal Science Department, University of Puerto Rico at Mayagüez. 


\title{
RESUMEN
}

\author{
Comparación de la termorregulación y productividad de vacas Holstein \\ puertorriqueñas de pelaje normal y de pelo corto
}

\begin{abstract}
Las vacas Holstein puertorriqueñas de pelaje normal (REGULARES), a través de anécdotas, han sido asociadas con un desempeño inferior al de vacas similares de pelo corto (PELONAS) cuando se exponen a un ambiente caliente. Sin embargo, existe poca evidencia científica al respecto. Por esto, se compararon sus temperaturas vaginales (TV), tamaño de glándulas de sudor (TGS) y producción de leche (PL). Los datos se analizaron mediante los procedimientos GLIMMIX y REG (SAS). Durante la época fresca (marzo 2014) se observaron valores similares de TV en vacas REGULARES y PELONAS (38.71 \pm 0.09 y $38.71 \pm 0.08^{\circ} \mathrm{C}$, respectivamente; $\left.\mathrm{P}=0.9634\right)$. Sin embargo, en la época con temperatura del aire (TA) intermedia (abril 2014) las vacas REGULARES presentaron TV $0.25^{\circ} \mathrm{C}$ mayores que las PELONAS de 1900 a 2100h $(P=0.0213)$. Aún más, en la época caliente (agosto 2015) las vacas REGULARES presentaron valores de TV mayores que las PELONAS por $0.31^{\circ} \mathrm{C}$ de 1800 a $0700 \mathrm{~h}$ y de 0900 a $1600 \mathrm{~h}(\mathrm{P}=0.0032)$ y por $0.20^{\circ} \mathrm{C}$ a las $0800 \mathrm{~h}(\mathrm{P}=0.0584)$ y $1700 \mathrm{~h}(\mathrm{P}=0.0619)$. La TV aumentó linealmente hasta que se alcanzaron los $30.5^{\circ} \mathrm{C}$ de TA, tanto en vacas REGULARES $\left(0.10^{\circ}\right.$ $\mathrm{C}$ por $1^{\circ} \mathrm{C}$ de TA; $\left.\mathrm{P}<0.0001\right)$ como en PELONAS $\left(0.08^{\circ} \mathrm{C}\right.$ por $1^{\circ} \mathrm{C}$ de TA; $\mathrm{P}<0.0001$ ). Después de $30.5^{\circ} \mathrm{C}$ de TA esta asociación desapareció. Las vacas REGULARES tuvieron menores TGS $(232 \pm 12$ vs. $315 \pm 9 \mu \mathrm{m}$ de perímetro; $P=0.0024)$ y de $P L(17.11 \pm 0.63$ vs. $20.26 \pm 1.28 \mathrm{~kg} / \mathrm{d}$; $P=0.0288)$ que las PELONAS. Las vacas PELONAS mostraron una capacidad termorreguladora superior, la cual parece depender directamente de la severidad de la TA.
\end{abstract}

Palabras clave: vacas Holstein pelonas puertorriqueñas, termorregulación, estrés por calor

\section{INTRODUCTION}

Puerto Rico's tropical weather is characterized by chronically elevated air temperature (AT) and humidity (Daly et al., 2003). In cattle, such environmental conditions are known to result in heat stress, which negatively impacts feed intake, milk production (Kadzere et al., 2002; West, 2003) and reproduction (Jordan, 2003). Unfortunately, Puerto Rico's dairy industry relies exclusively on temperate Bos taurus cattle (e.g., Holstein), which are highly susceptible to heat stress, compared with tropically adapted cattle (Sánchez-Rodriguez, 2019). Therefore, attempts to improve productivity under such environmental conditions are imperative.

Fortunately, besides the wild type-haired cows (WT; with long and dense hair coats), a short and sleek-haired phenotype (SLICK) also exists among Puerto Rico's dairy cattle. These SLICK cattle originated from crossbreeding the Puerto Rican Criollo cows with improved dairy genetics beginning in the 1950s (Sánchez-Rodriguez, 2019). These Criollo cows had the short-haired phenotype (Sánchez-Rodriguez, 2019), which is believed to be a dominant trait (Olson et al., 2003), allowing this characteristic to be inherited until today in a portion of Puerto Rico's 
dairy cattle population. Since then, an intense artificial insemination program, as well as natural breeding with imported bulls, has continually added more Holstein genes to these animals to the point that today there are SLICK Puerto Rican Holsteins registered under this breed in association herd books in the USA.

During recent years, an enormous interest in SLICK dairy cattle has developed based on the belief of superior performance in hot weather compared with similar WT cattle. In fact, in other breeds or crosses from different countries, having such a short hair coat has been associated with superior thermoregulation (Olson et al., 2003; Dikmen et al., 2008; Dikmen et al., 2014). Moreover, besides presenting a shorter hair coat, tropically adapted cattle also have larger sweat glands (Finch, 1986), hematocrit values (Gaztambide, 1974; Turner, 1980) and milk yields (Olson et al., 2003). In Puerto Rico, however, the assumption of a better performance in the SLICK animals has been based mostly on anecdotes, and the amount of scientific research evaluating such possible differences has been highly limited. Thus, this manuscript aims to present a series of scientific comparisons between both phenotypes in terms of thermoregulation, sweat gland dimensions, hematocrit values and milk production.

\section{MATERIALS AND METHODS}

This manuscript compiles the principal results obtained under project H-452 (USDA National Institute of Food and Agriculture, Hatch funding) and presented preliminarily in posters by Sánchez-Rodríguez et al. (2015), Contreras-Correa et al. (2016), Sánchez-Rodríguez et al. (2016), Contreras-Correa et al. (2017), Sánchez and Domenech (2018) and Muñiz-Cruz et al. (2018). All performed trials were approved by the University of Puerto Rico, Mayagüez Campus, Institutional Animal Care and Use Committee (Proposal number 20140711A).

\section{Vaginal temperature comparisons between phenotypes}

\section{Trials}

In order to compare the vaginal temperatures (VT; as an index of thermoregulatory capacity) of WT and SLICK cows, three trials were carried out. Trial dates were chosen according to Daly et al. (2003) data [who averaged Puerto Rico's AT monthly values from 1963-1995 (Figure 1)], and the availability of the animals. In order to compare hair coat type thermoregulation during the cool, intermediate and hot seasons of the year, trials were carried out during March 2014, April 2014 and August 2015, respectively. Table 1 provides the AT ranges and duration of each trial. 


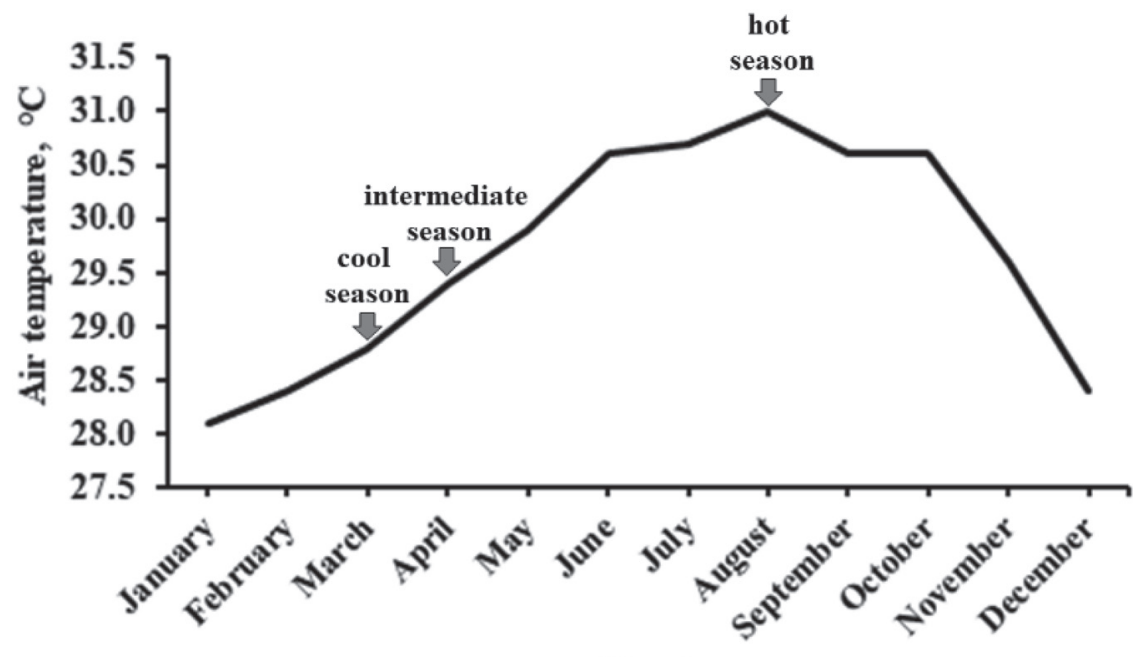

Month

Figure 1. Mean air temperature values in Puerto Rico all year round [Modified from Daly et al. (2003)] and the seasons evaluated in the present study (gray arrows). Trials for thermoregulatory comparisons between hair coat types were carried out in March 2014, April 2014 and August 2015 and were characterized as cool, intermediate and hot seasons, respectively.

\section{Animals}

Description of the evaluated cows are provided in Table 1. For the cool, intermediate and hot seasons a total of nine (4 WT and 5 SLICK), 10 (5 WT and 5 SLICK) and 24 (11 WT and 13 SLICK) non-pregnant lactating Holstein cows were evaluated, respectively. All cows were obtained from the experimental herd at the Agricultural Experiment Station of the University of Puerto Rico in Lajas. Cows were first phenotypically chosen and then genomically confirmed for hair coat type. Phenotypic classifications were made visually by the author, where cows with a short, sometimes glossy hair coat all around their bodies were classified as SLICK and cows with the normal Holstein hair coat were classified as WT. The genomic classifications were kindly provided by Dr. Melvin Pagán (University of Puerto Rico at Mayagüez) who had already classified the herd based on the procedures previously described by Littlejohn et al. (2014). Cows that visually presented an intermediate hair coat length or whose phenotypic and genomic classifications differed were excluded from the study. Regular management practices at the farm were maintained during all trials. Cows were milked twice daily, at 0300 and $1500 \mathrm{~h}$, and commercial concentrate feed was provided before each milking (approximately $3 \mathrm{~kg} / \mathrm{cow} / \mathrm{milk}$ - 
J. Agric. Univ. P.R. voL. 103, No. 1, 2019

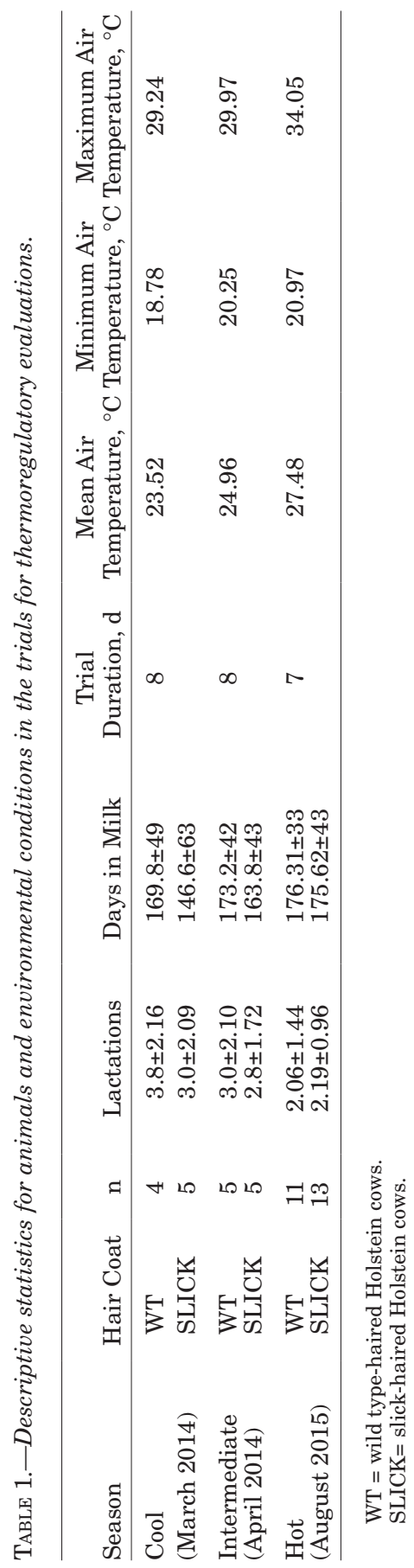


ing). Cows were brought to the feeding facilities 30 to 60 minutes prior to milking and udders were washed while concentrate was offered. During the remaining daily period, cows were kept in a paddock with native tropical grasses. Water was provided ad libitum in all facilities. Due to the changes in the availability of lactating non-pregnant cows that normally occur as lactation progresses, all trials were carried out with the animals available at the respective trial time.

\section{Air temperature}

Air temperature was recorded in each trial by two data loggers (HOBO Pro v2 temp/RH Data Logger; Onset Computer Corporation; Bourne, MA, USA) $)^{4}$ located at the feeding barn. Mean, minimum and maximum observed AT values for each trial are provided in Table 1. Data loggers recorded AT values every 5 minutes for the total duration of the trial (Table 1).

\section{Vaginal temperature}

The day before the trials began, each cow received a waterproof data logger (TidbiT v2 Water Temperature Data Logger; Onset Computer Corporation; Bourne, MA, USA) tied to a controlled internal drug release device (CIDR; Pfizer Ireland, Dublin, Ireland). Data loggers and CIDRs were implanted intravaginally following aseptic practices. Before attaching the data loggers, CIDRs were washed with alcohol, water and soap and autoclaved. Immediately before intravaginal insertion, the data loggers + CIDRs and external genitalia of each cow were washed with surgical soap (Stone Surgical Soap, Stone Mfg \& Supply, $\mathrm{KC}, \mathrm{MO}, \mathrm{USA}$ ) and disinfected with a chlorhexidine solution (Nolvasan, Fort Dodge Animal Health, Fort Dodge, IA, USA). Everything was dried with a clean paper towel, and sterile lubricant (K-Y Jelly, Reckitt Benkshire Group, Slough, Berkshire, UK) was applied to the data logger and CIDR immediately before its insertion by means of a CIDR applicator gun. Vaginal data loggers were programmed to record temperature data every 5 minutes in synchrony with the AT data loggers.

The VT data were analyzed by PROC GLIMMIX in SAS (SAS Inst., Inc., Cary, NC, USA). Before comparisons between hair coat types were made, the VT data were averaged by hour in order to obtain 24 values/cow/day. The average VT was included as the dependent variable in the model, while time of day and hair coat type were considered

${ }^{4}$ Company or trade names in this publication are used only to provide specific information. Mention of a company or trade name does not constitute an endorsement by the Agricultural Experiment Station of the University of Puerto Rico, nor is this mention a statement of preference over other equipment or materials. 
fixed effects. Cow identification numbers were included as a random effect. The CORR procedure was used to evaluate the associations between the AT and VT in each hair coat type group and trial in the raw data (every 5 minutes). Results are reported as mean \pm standard error of the mean. Significant differences were detected at a $\mathrm{P} \leq 0.05$.

\section{Vaginal and air temperatures regressions}

During the hot season trial (August 2015), the association between the VT and AT was assessed in each hair coat type group by the GLM and REG procedures in SAS. Data were averaged to obtain one value by hair coat group every $5 \mathrm{~min}$. Regressions were made in order to study the critical AT values where cows were not able to further regulate efficiently their VT. First, the curve that best fits the relationship between VT and AT in each hair coat type group in the complete dataset was determined. Second, in the first segment of each hair coat group's curve, corresponding AT and VT values were progressively added to a linear regression until a considerable change in the coefficient of determination $\left(\mathrm{R}^{2}\right)$ was observed (the curves are not linear anymore). The AT value where the $R^{2}$ changed considerably was considered critical for thermoregulation.

\section{Sweat gland comparisons}

Table 2 contains descriptive statistics for the cows used in two different trials for comparing sweat glands between hair coat groups. A total of 14 (7 WT and 7 SLICK) and 17 (8 WT and 9 SLICK) lactating Holstein cows were used in the first and second trials, respectively. Cows were first phenotypically chosen and then genomically confirmed for hair coat type, as aforementioned. All cows were obtained from the experimental herd at the Agricultural Experiment Station of the Uni-

TABLE 2.-Descriptive statistics for the trials comparing sweat gland size, hematocrit and milk production values between hair coat types.

\begin{tabular}{llcc}
\hline Trial & Hair coat & $\mathrm{n}$ & Lactations \\
\hline Trial 1 & & & \\
Sweat glands & WT & 7 & $2.28 \pm 0.64$ \\
& SLICK & 7 & $2.86 \pm 0.51$ \\
Trial 2 & & & \\
Sweat glands & WT & 8 & $2.39 \pm 0.17$ \\
& SLICK & 9 & $3.71 \pm 0.26$ \\
Hematocrit and milk production & WT & 35 & $1.94 \pm 0.25$ \\
& SLICK & 29 & $2.17 \pm 0.22$ \\
\hline
\end{tabular}

WT = wild type-haired Holstein cows.

SLICK = slick-haired Holstein cows. 
versity of Puerto Rico in Lajas. From each cow, two and one skin biopsies ( $6 \mathrm{~mm}$ in diameter) were collected immediately cranial to the right shoulder after local anesthesia infiltration in Trials 1 and 2, respectively. Biopsies were fixed in $10 \%$ formalin, embedded in paraffin, sectioned perpendicular to the skin surface (histological sections of 7 $\mu \mathrm{m}$ in thickness), and stained with hematoxylin and eosin (Figure 2). In Trial 1, from each biopsy, one microscopic slide was prepared containing three histological sections. In Trial 2, a total of six histological sections per cow were included in a microscopic slide. Microscopic images $(4 x)$ were analyzed by the NIS Element D software (Nikon, Melville, NY), evaluating all the cross-sectional cuts of sweat glands per histological section $(39.01 \pm 11.97$ cuts / section). In Trial 1 the crosssectional cuts of sweat glands area (SGA) and perimeter (SGP), as well as the skin thickness (ST; from the epidermis to the deep layer of the dermis) were determined. The ST was measured in triplicate from each histological section. In Trial 2, only SGA was recorded. In Trials 1 and 2 , data were averaged by microscopic slide and by skin cut, respectively. Averaged data were analyzed using the GLIMMIX procedure of SAS. The sweat gland dimensions and ST were included as dependent

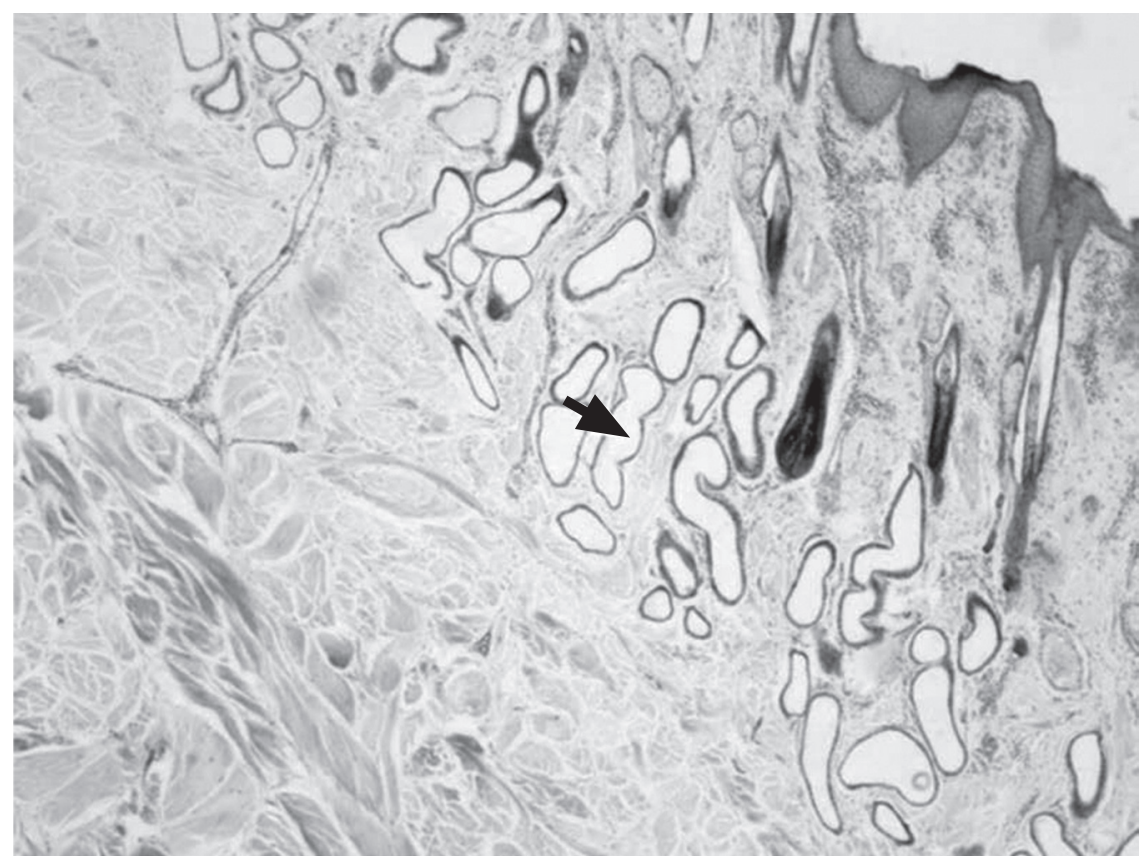

FIGURE 2. Microscopic image of a histological section of a cow's skin. Note the arrow pointing to one of the sweat gland cross-sectional cuts. 
variables of the model, while the hair coat type was considered a fixed effect. The cow identification numbers were included as a random effect. Differences were detected at a significance level of $\mathrm{P} \leq 0.05$.

\section{Hematocrit and milk production values}

The descriptive statistics for the cows included in the hematocrit and milk production comparisons are provided in Table 2. Additionally, WT and SLICK groups were balanced by body weight $(538.25 \pm 12$ vs. $570.31 \pm 16 \mathrm{~kg} ; \mathrm{P}=0.5098)$, DIM ( $187.57 \pm 16$ vs. $186.90 \pm 18 ; \mathrm{P}=0.9992)$, and lactation number $(1.94 \pm 0.25$ vs. $2.17 \pm 0.22$; $\mathrm{P}=0.9984)$. Cows belonging to the experimental herd at the Agricultural Experiment Station of the University of Puerto Rico in Lajas were phenotypically chosen and genomically confirmed for hair coat type, as previously described.

Coccygeal blood samples (1/cow) were obtained in $6 \mathrm{~mL}$ Lithium Heparin collection tubes (BD Vacutainer, Franklin Lakes, NJ, USA). Once sealed, from each vacutainer, three StatSpin ${ }^{\circledR}$ micro-HCT tubes (heparinized glass; StatSpin Technologies, Norwood, MA) were filled with blood by capillary force and spun in a StatSpin ${ }^{\circledR}$ microcentrifuge (120 seconds, 2,500 rpm; StatSpin Technologies, Norwood, MA). The micro-HTC tubes were evaluated in a StatSpin ${ }^{\circledR}$ Illuminated micro$\mathrm{HCT}$ reader. The micro-hematocrit values were determined as the portion of the total blood volume occupied by red blood cells. All blood samples were collected in the morning $(0700-0800 \mathrm{~h})$, after the first milking and with all cows having ad libitum access to drinking water. Hematocrit data were recorded in triplicate and averaged by cow. Additionally, daily milk production data (averaged from the week before hematocrit sampling) was obtained from the AfiFarm herd management software (S. A. E. Afikim, Kibbutz Afikim, Israel).

Data were analyzed using the GLIMMIX procedure of SAS. The hematocrit and milk production values were included as the dependent variables in the model. Hair coat type and the cow identification numbers were considered the fixed and random effects of the model, respectively. Differences were detected at a $\mathrm{P} \leq 0.05$.

\section{RESULTS AND DISCUSSION}

\section{Vaginal temperature comparisons}

Figure 3 presents the VT trends observed during the cool season. No differences in VT were observed between WT and SLICK cows (38.71 \pm 0.09 and $38.71 \pm 0.08{ }^{\circ} \mathrm{C}$, respectively; $\mathrm{P}=0.9634$ ). However, during the intermediate season (Figure 4), hair coat type and time of day 


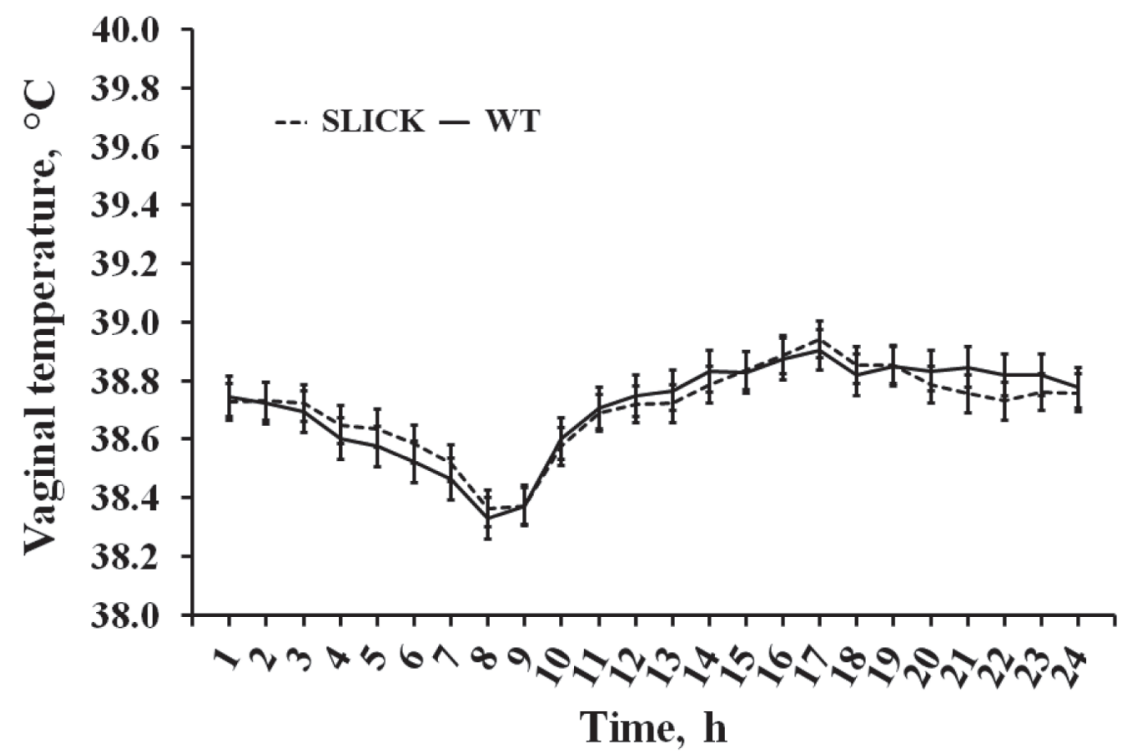

FIGURE 3. Vaginal temperature trends in wild type (WT) and slick-haired (SLICK) Holstein cows during the cool season (March 2014). Hair coat type ( $\mathrm{P}=0.9634)$.

interacted to affect VT $(\mathrm{P}<0.0001)$ with WT cows presenting VT values $0.25^{\circ} \mathrm{C}$ greater than SLICK cows from 1900 to $2100 \mathrm{~h}(\mathrm{P}=0.0213)$. In the remaining daily period $(2200$ to $1800 \mathrm{~h}) \mathrm{WT}$ and SLICK cows presented similar VT values $\left(38.68 \pm 0.10\right.$ and $38.60 \pm 0.07{ }^{\circ} \mathrm{C}$ on average, respectively; $\mathrm{P}=0.3924$ ). Moreover, during the hot season (Figure 5 ) there was also an interaction between hair coat type and time of day affecting the VT $(\mathrm{P}=0.0026)$ with WT cows presenting, on average, $0.31^{\circ} \mathrm{C}$ greater VT values than their SLICK counterparts from 1800 to $0700 \mathrm{~h}$ and from 0900 to $1600 \mathrm{~h}(\mathrm{P}=0.0032)$. During the $0800 \mathrm{~h}$ $(\mathrm{P}=0.0584)$ and $1700 \mathrm{~h}(\mathrm{P}=0.0619) \mathrm{VT}$ values tended to be, on average, $0.20^{\circ} \mathrm{C}$ greater in WT than in SLICK cows.

Similar to the present cool season trial, another study from our group (Castro et al., 2015) did not find differences in VT between WT and SLICK Puerto Rican Jersey cows in December 2014. In fact, the trials that previously reported body temperature differences between hair coat types in the literature, have always been performed during the hot season of the year. Dikmen et al. (2008) and Dikmen et al. (2014) reported higher VT values in WT than in SLICK Holstein cows (derived from Senepol x Holstein crossbreds) during the hot season (July - August) in Florida, USA. Also in Florida, Olson et al. (2003) observed greater rectal temperatures in WT beef calves [Angus purebreds or Angus x (Sene- 


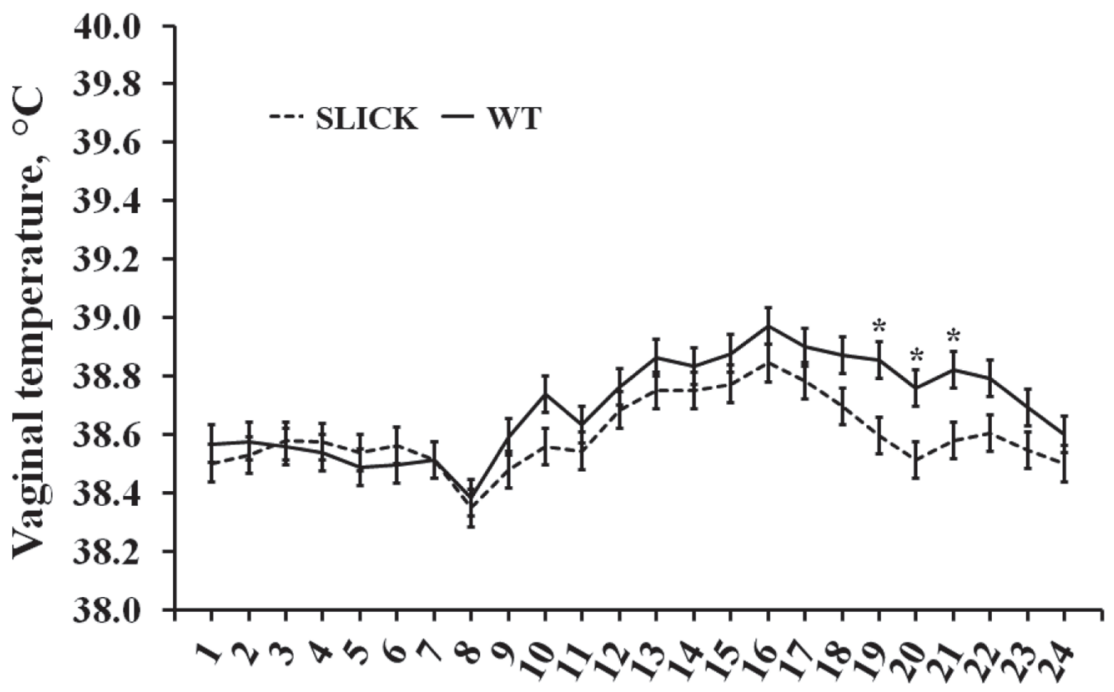

FIGURE 4. Vaginal temperature trends in wild type (WT) and slick-haired (SLICK) Holstein cows during the intermediate season (April 2014). *Hair coat type x Daily time $(P<0.0001)$.

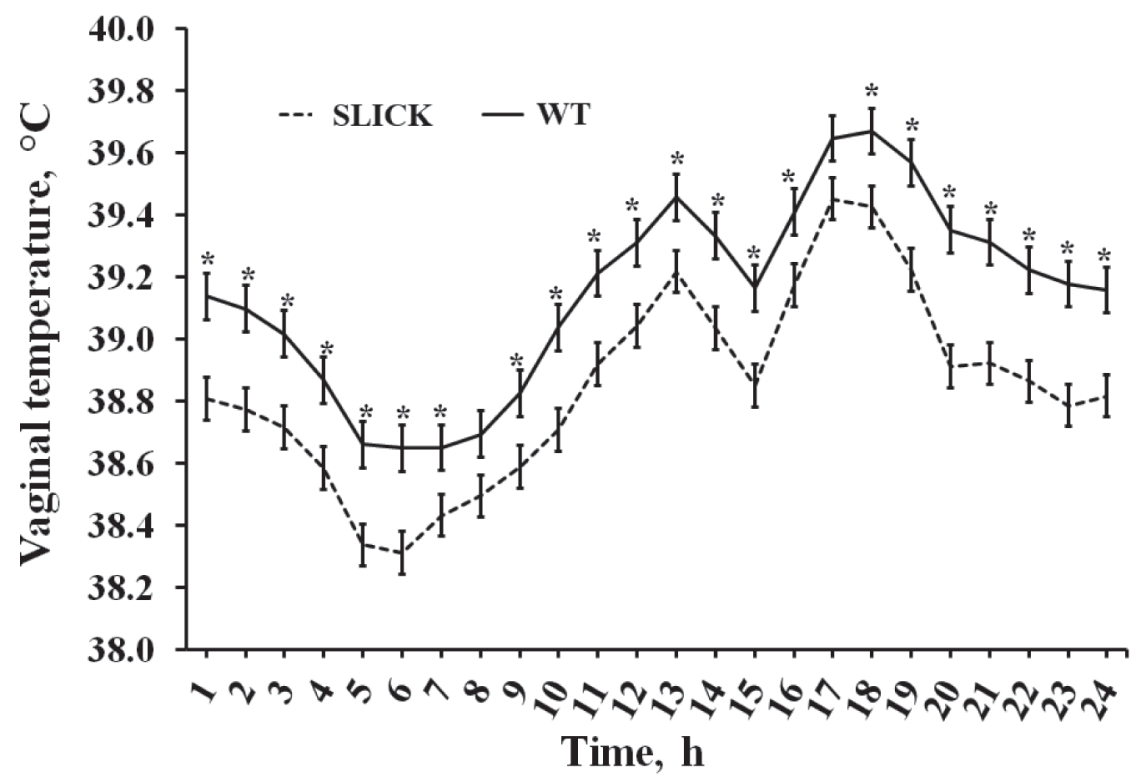

FIGURE 5. Vaginal temperature trends in wild type (WT) and slick-haired (SLICK) Holstein cows during the hot season (August 2015). *Time $\mathrm{x}$ Hair type ( $\mathrm{P}=0.0026)$; Hair type $(\mathrm{P}=0.0032)$; Time $(\mathrm{P}<0.0001)$. 
pol x Hereford) crossbred] than in their crossbred SLICK counterparts, during the hot season (July - August). However, even when Castro et al. (2015) did not observe VT differences during the cool season, they reported greater respiration rates in the WT than in the SLICK Jersey cows, suggesting a greater effort to maintain thermal homeostasis in the first group. In fact, in the present study the correlation coefficients between the VT and AT show a greater environmental impact on the WT than on the SLICK cows in all three seasons (Table 3). The physical barrier created between the skin and the environment by the hair coat limits heat dissipation by trapping water vapor in WT Bos taurus cattle exposed to hot and humid weather (Finch, 1986). Therefore, WT cows may require additional effort to maintain thermal homeostasis under our environmental conditions during the cool season. However, it seems that during hot weather, such increased respiratory rate may not be enough to avoid an increase in body temperature in WT cows. Thus, the magnitude of the differences in body temperature between hair coat types seems to be directly associated with the severity of the environmental conditions surrounding the animal.

Contrary to our study, however, Olson et al. (2003) reported greater rectal temperatures in WT beef calves than in their SLICK counterparts during the cool season (November and December) in Florida, USA. Since Florida has relatively cold winters (in contrast to Puerto Rico), it is possible that the evaluated WT beef calves had a consider-

TABLE 3.-Pearson coefficients of correlation between air and vaginal temperature in wild type (WT) and slick-haired (SLICK) Holstein cows during the seasons evaluated.

\begin{tabular}{ccc}
\hline & \multicolumn{2}{c}{ Cool season (March 2014) Vaginal temperature } \\
\cline { 2 - 3 } & WT & SLICK \\
\hline & 0.53 & 0.46 \\
Air temperature & 0.0074 & 0.0223
\end{tabular}

\begin{tabular}{ccc} 
& \multicolumn{2}{c}{ Intermediate season (April 2014) Vaginal temperature } \\
\cline { 2 - 3 } & $\mathrm{WT}$ & SLICK \\
\hline Air temperature & 0.74 & 0.66 \\
& $<0.0001$ & 0.0004
\end{tabular}

\begin{tabular}{ccc} 
& Hot season (August 2015) & Vaginal temperature \\
\cline { 2 - 3 } & $\mathrm{WT}$ & SLICK \\
\hline Air temperature & 0.64 & 0.61 \\
& $<0.0001$ & $<0.0001$ \\
\hline
\end{tabular}

The presented values are the Pearson coefficients of correlation over their respective P-Values. 
ably limited adaptation to hot weather, allowing further advantages associated with the SLICK phenotype to be observed during the cool season. Bligh and Johnson (1973) defined the term adaptation as "a change which reduces the physiological strain produced by a stressful component of the total environment" that may be "the result of genetic selection". In this regard, a considerable part of the WT Puerto Rican dairy cattle population has been on the island for generations; thus, although to a smaller degree than in the SLICK cows (Table 3), considerable genetic selection and adaptation to the hot and humid tropical environmental conditions may be reasonably expected in these animals (Sánchez, 2019). This may help to explain the lack of VT differences between hair coat types during the cool season.

\section{Vaginal and air temperature regressions}

Due to the considerable effects that heat stress exerts on cattle productivity, several authors have evaluated the critical thresholds in the environmental conditions where bovines cannot further maintain thermal homeostasis. In Bos taurus dairy cattle under desert conditions (Berman, 1971; Berman et al., 1985) and beef cattle under temperate weather conditions (Lefcourt and Adams, 1996), these studies have concluded that once the AT reaches $25-26^{\circ} \mathrm{C}$, the animal cannot further maintain a steady body temperature, and a linear increase is observed in this variable. Figure 6 shows the regressions between

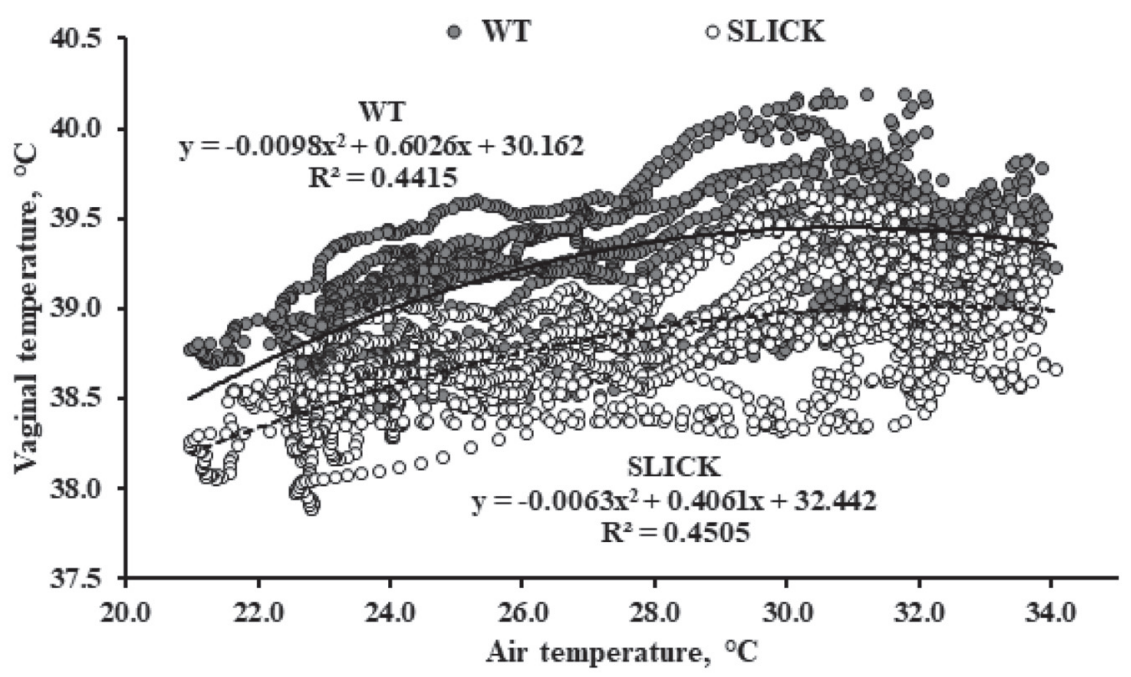

FIGURE 6. Regressions between the vaginal and air temperatures in wild type (WT) and slick-haired (SLICK) Holstein cows during the hot season (August 2015). 
VT and AT in the evaluated hair coat groups during the hot season. For WT cows, the relationship between AT and VT was best described by a quadratic curve, where $\mathrm{VT}=-0.0098 \mathrm{AT}^{2}+0.6026 \mathrm{AT}+30.162$ $\left(\mathrm{R}^{2}=0.44 ; \mathrm{P}<0.0001\right)$. In the SLICK cows the respective regression was also best explained by the quadratic relationship: $\mathrm{VT}=-0.0063 \mathrm{AT}^{2}+$ $0.4061 \mathrm{AT}+32.442\left(\mathrm{R}^{2}=0.45 ; \mathrm{P}<0.0001\right)$. These quadratic trends were the result of two linear segments. The VT values linearly increased in both, WT $\left(0.10^{\circ} \mathrm{C}\right.$ per $1^{\circ} \mathrm{C}$ of $\left.\mathrm{AT} ; \mathrm{P}<0.0001 ; \mathrm{R}^{2}=0.42\right)$ and SLICK cows $\left(0.08^{\circ} \mathrm{C}\right.$ per $1^{\circ} \mathrm{C}$ of $\left.\mathrm{AT} ; \mathrm{P}<0.0001 ; \mathrm{R}^{2}=0.43\right)$ until the $\mathrm{AT}$ reached $30.5^{\circ}$ C. After this critical value, VT was no longer affected by AT, for neither WT $\left(\mathrm{P}=0.0602 ; \mathrm{R}^{2}=0.006\right)$ nor SLICK cows $\left(\mathrm{P}=0.6536 ; \mathrm{R}^{2}=0.0003\right)$. Thus, Puerto Rican Holstein cows seems to withstand AT values considerably higher than those previously reported as critical for thermoregulation in bovines.

Besides the aforementioned considerable adaptation of the Puerto Rican WT cattle, their SLICK counterparts descend from our Criollo cattle, where the Holstein genes have been intensively introduced mostly through artificial insemination for over 70 years (Sánchez, 2019). The Criollo cattle (with Spanish origins) developed after several centuries of mostly natural selection in Puerto Rico and other Hispanic countries in America (Rouse, 1977; McTavish et al., 2013), becoming highly adapted to the tropical weather (Cestero, 1947; Bethancourt and Toribio, 2013; Huson et al., 2014). Thus, the actual SLICK dairy animals would have inherited other genes associated with adaptation to hot weather, and the critical environmental thresholds previously established in the literature for Bos taurus cattle thermoregulation do not represent the reality of the Puerto Rican cattle.

\section{Sweat gland comparisons}

A shorter hair coat may be an important characteristic allowing for a greater heat dissipation in SLICK cows during hot weather. However, such superior thermoregulatory capacity may not only be attributed to a shorter hair coat since it must be multifactorial in nature. In fact, Finch (1986) also established that tropically adapted cattle should be able to increase their sweating rate as body temperature increases in an attempt to maintain thermal homeostasis. In this regard, two trials comparing the sweat gland-related dimensions between hair coat groups are presented in Table 4 . The first trial showed smaller values of SGA $\left(3,169 \pm 306\right.$ vs. $\left.6,009 \pm 335 \mu^{2} ; \mathrm{P}=0.0008\right)$, SGP $(232 \pm 12$ vs. $315 \pm 9 \mu \mathrm{m} ; \mathrm{P}=0.0024)$ and $\mathrm{ST}(808 \pm 23$ vs. $1,006 \pm 34 \mu \mathrm{m} ; \mathrm{P}=0.0027)$ in the WT cows, when compared with their SLICK counterparts. This trend was confirmed in the second trial where the SGA values were also smaller in the WT than in the SLICK cows $(4,902.67 \pm 588$ and 
TABLE 4.—Sweat gland, hematocrit and milk production comparisons between wild type (WT) and slick-haired (SLICK) Holstein cows.

\begin{tabular}{lccc}
\hline & \multicolumn{3}{c}{ Trial 1 Sweat glands } \\
\cline { 2 - 4 } & $W T(n=7)$ & SLICK $(n=7)$ & P-Value \\
\hline Skin thickness, $\mu \mathrm{m}$ & $808 \pm 23$ & $1,006 \pm 34$ & 0.0027 \\
Sweat gland area, $\mu^{2}$ & $3,169 \pm 306$ & $6,009 \pm 335$ & 0.0008 \\
Sweat gland perimeter, $\mu \mathrm{m}$ & $232 \pm 12$ & $315 \pm 9$ & 0.0024 \\
\hline
\end{tabular}

Trial 2 Sweat glands

\begin{tabular}{lccc}
\cline { 2 - 4 } & WT $(n=8)$ & SLICK $(n=9)$ & $P$-Value \\
\hline Sweat gland area, $\mathrm{\mu m}^{2}$ & $4,902.67 \pm 588$ & $6,946.16 \pm 623$ & 0.0307 \\
\hline
\end{tabular}

Hematocrit trial

\begin{tabular}{lrrr}
\hline & WT $(n=35)$ & SLICK $(n=29)$ & $P$-Value \\
\hline Hematocrit, \% & $29.30 \pm 0.46$ & $29.79 \pm 0.49$ & 0.4040 \\
\hline
\end{tabular}

\begin{tabular}{lcrc} 
& \multicolumn{3}{c}{ Milk production trial } \\
\cline { 2 - 4 } & $W T(n=35)$ & SLICK $(n=29)$ & P-Value \\
\hline Milk Production, $\mathrm{kg} / \mathrm{d}$ & $17.11 \pm 0.63$ & $20.26 \pm 1.28$ & 0.0288 \\
\hline
\end{tabular}

The sweat gland area and perimeter were obtained from cross-sectional cuts of sweat glands on histological sections in a microscopic slide.

6,946.16 $\pm 623 \mu \mathrm{m}^{2}$, respectively; $\left.\mathrm{P}=0.0307\right)$. These results are consistent with those previously published by others who have established that tropically adapted Bos indicus (Hansen, 2004; Jian et al., 2014) and Bos taurus cattle (Carvalho et al., 1995; Ribeiro, 2008 as reviewed by Fernandes) have larger sweat glands than WT temperate Bos taurus breeds. According to Jian et al. (2014), a larger sweat gland size is accompanied by a greater sweating capacity in Bos indicus cattle. If such a trend exists in SLICK Holstein cattle, as reported by Dikmen et al. (2014) in cows derived from Senepol x Holstein crossbreds, a larger sweat gland may represent a better heat dissipation through evaporation, thus helping to explain the aforementioned differences in body temperature between hair coat groups.

\section{Hematocrit values}

Several previous authors have suggested a higher hematocrit level as one of the adaptations that make tropical cattle able to withstand difficult environmental conditions (Gaztambide, 1974; Turner, 1980). In their article, Hernández et al. (2002) reviewed two possible explanations for such thermoregulatory capacity. A greater hematocrit may 
allow for better respiratory efficiency and lower respiratory rates with a smaller subsequent heat production, or tropically adapted cattle may require a smaller water intake for thermoregulation, thus avoiding hemodilution. However, in our study (Table 4) there were no differences in the hematocrit values between the WT and SLICK cows $(29.30 \pm 0.46$ vs. $29.79 \pm 0.49 \%$, respectively; $\mathrm{P}=0.4040$ ). Thus, this appears not to be an adaptation achieved by the Puerto Rican SLICK cattle.

\section{Milk production}

Table 4 also contains a comparison of daily milk production values between WT and SLICK Holstein cows. The WT cows presented smaller milk production values than their SLICK counterparts $(17.11 \pm 0.63$ vs. $20.26 \pm 1.28 \mathrm{~kg} / \mathrm{d} ; \mathrm{P}=0.0288$, respectively). These results correspond to those previously reported by others in cattle with diverse genotypes. Delgado et al. (2014) reported lower milk yields in WT than in SLICK cows in both Jersey and Holstein cattle from a commercial dairy farm in Puerto Rico. Dikmen et al. (2014) observed that the decrease in milk production observed during the summer in Florida was larger in WT Holstein cows (resulting from Senepol x Holstein mating) than in their SLICK counterparts. Olson et al. (2003) observed a smaller 305-d milk yield in WT than in SLICK Holstein x Carora cows in Venezuela. Therefore, under hot environmental conditions the SLICK phenotype may be advantageous in terms of productivity. The capacity of the SLICK cows to keep grazing under the tropical sun, while their WT counterparts rest in the shade (Sánchez-Rodriguez, 2019) may help to explain this superiority.

\section{CONCLUSIONS}

Even though WT Puerto Rican cattle have achieved considerable adaptation to tropical weather, their SLICK counterparts showed greater thermoregulatory capacity. Such superiority seems to be directly dependent on the severity of the environmental conditions; the higher the AT, the greater the differences in VT between phenotypes. Both hair coat type groups, but especially the SLICK one, were able to avoid a significant relationship between their VT and the environment at considerably higher AT values than those previously reported in the literature as critical for thermoregulation in Bos taurus cattle. Differences in sweat gland size between hair coat groups may help to explain the observed thermoregulatory trends. Concurrently with a higher VT, WT cows presented lower milk production than the SLICK ones. Future studies should be directed to evaluate if the differences in sweat gland size between hair coat groups result in different sweating rates and heat dissipation through evaporation. 


\section{LITERATURE CITED}

Berman, A., 1971. Thermoregulation in intensely lactating cows in near-natural conditions. J. Physiol. Lond. 215: 477-481.

Berman, A., Y. Folman, M. Kaim, M. Mamen, Z. Herz, D. Wolfenson, A. Arieli and Y. Graber, 1985. Upper critical temperatures and forced ventilation effects for highyielding dairy cows in a subtropical climate. J. Dairy Sci. 68: 1488-1495.

Bethancourt, H. and B. Toribio, 2013. Caracterización genética del ganado Criollo Lechero Dominicano utilizando microsatélites. Revista Agropecuaria y Forestal APF. 2(1): 43-48.

Bligh, J. and K.G. Johnson, 1973. Glossary of terms for thermal physiology. J. Appl. Physiol. 35(6): 941-961.

Carvalho, F.A., M.A. Lammoglia, M.J. Simoes and R.D. Randel, 1995. Breed affects thermoregulation and epithelial morphology in imported and native cattle subjected to heat stress. J. Anim. Sci. 73: 3570-3573.

Castro, A., G. Muñiz, J. Curbelo, M. Pagán, A. Mesonero, A. de Jesús, N. Lluch and H. Sánchez, 2015. Effect of the environmental conditions over the vaginal temperature and respiration rate on wild type and slick-haired Puerto Rican Jersey cows. Joint Annual Meeting ADSA-ASAS 2015. Orlando, Florida. July 12, 2015.

Cestero, H.R., 1947. Crossbreeding as a means to improve dairy cattle in Puerto Rico. Thesis for the Master of Science. Department of Dairy Husbandry. Kansas State College of Agriculture and Applied Science.

Contreras-Correa, Z., G. Muñiz-Colón, M. Pagán-Morales, A. Mesonero-Morales, J. Curbelo-Rodríguez and H.L. Sánchez-Rodríguez, 2016. Hematocrit, milk yield, and production related parameters comparisons between slick and wild type-haired Puerto Rican Holstein cows. Joint Annual Meeting, ASAS-ADSA-CSAS-WSASAS. Salt Lake City, Utah. July 19-23, 2016.

Contreras-Correa, Z.E., N. Peña-Alvarado, W. Torres-Ruiz, J. R. Almodóvar-Rivera, K. I. Domenech-Pérez, C. Youngblood, M. Pagán-Morales, A. Mesonero-Morales, J. Curbelo-Rodríguez, P.F. Randel-Follin, G.C. Muñiz-Colón, V. Colón-González, Á.L. Jiménez-Arroyo, G.M. Jiménez-Arroyo and H.L. Sánchez-Rodríguez, 2017. Slickhaired Puerto Rican Holstein cows have larger sweat glands than their wild typehaired counterparts. ADSA 2017. Pittsburgh, Pennsylvania. June 25-28, 2017.

Daly, C., E.H. Helmer and M. Quiñones, 2003. Mapping the climate of Puerto Rico, Vieques, and Culebra. Int. J. Climatol. 23: 1359-1381.

Delgado, R., G. Colón, Z. Crespo, V. Colón, P. Cordero, G. Vargas, E. Lozada, E. Arcelay, C. Cabrera, E. Riquelme, G. Muñiz, A. de Jesus, N. Lluch and H. Sánchez, 2014. Asociación entre raza, tipo de pelo y producción de leche en vacas lecheras en Puerto Rico. Reunión Científica de la Sociedad Puertorriqueña de Ciencias Agrícolas. Rincón of the Seas. Rincón, PR. November, 2014.

Dikmen, S., E. Alava, E. Pontes, J. M. Fear, B. Y. Dikmen, T. A. Olson and P. J. Hansen, 2008. Differences in thermoregulatory ability between slick-haired and wild-type lactating Holstein cows in response to acute heat stress. J. Dairy Sci. 91: 3395-3402.

Dikmen, S., F.A. Khan, H.J. Huson, T.S. Sonstegard, J.I. Moss, G.E. Dahl and P.J. Hansen, 2014. The SLICK hair locus derived from Senepol cattle confers thermotolerance to intensively managed lactating Holstein cows. J. Dairy Sci. 97(9): 5508-5520.

Fernandes, J., 2011 Understanding how Saphire's Program evaluates the Senepol breed and the criteria used to identify superior Senepol heifers in Brazil. Grama Senepol Brazil.

Finch, V.A., 1986. Body temperature in beef cattle: Its control and relevance to production in the tropics. J. Anim. Sci. 62: 531-542.

Gaztambide, C., 1974. Ganado vacuno: Su aclimatación, cuido y manejo en los trópicos. Talleres de Artes Gráficas. Departamento de Instrucción Pública. San Juan, PR.

Hansen, P.J., 2004. Physiological and cellular adaptations of zebu cattle to thermal stress. Anim. Reprod. Sci. 82-83: 349-360.

Hernández, A.I., D. Cianzio and T.A. Olson. 2002. Physiological performance and grazing behavior of Senepol, Brahman and Holstein heifers in Puerto Rico. Senepol Symposium, St. Croix, USVI November 8-10. 
Huson, H.J., E.S. Kim, R.W. Godfrey, T.A. Olson, M.C. McClure, C.C. Chase, R. Rizzi, A.M.P. O’Brien, C.P. Van Tassell, J.F. García and T.S. Sonstegard, 2014. Genomewide association study and ancestral origins of the slick-hair coat in tropically adapted cattle. Front. Genet. 5:101: 1-12.

Jian, W., M. Duangjinda, C. Vajrabukka and S. Katawatin, 2014. Differences of skin morphology in Bos indicus, Bos taurus, and their crossbreds. Int. J. Biometeorol. 58: 1087-1094.

Jordan, E.R., 2003. Effects of heat stress on reproduction. J. Dairy Sci. 86: (E. Suppl.): E104-E114.

Kadzere, C.T., M.R. Murphy, N. Silanikove and E. Maltz, 2002. Heat stress in lactating dairy cows: A review. Livest. Prod. Sci. 77(1): 59-91.

Lefcourt, A. and W. Adams, 1996. Radiotelemetry measurement of body temperatures of feedlot steers during summer. J. Anim. Sci. 74: 2633-2640.

Littlejohn, M.D., K.M. Henty, K. Tiplady, T. Johnson, C. Harland, T. Lopdell, R.G. Sherlock, W. Li, S.D. Lukefahr, B.C. Shanks, D.J. Garrick, R.G. Snell, R.J. Spelmanand S.R. Davis, 2014. Functionally reciprocal mutations of the prolactin signaling pathway define hairy and slick cattle. Nature Communications. 5: 1-8.

McTavish, E.J., J.E. Decker, R.D. Schnabel, J.F. Taylor and D.M. Hillis, 2013. New World cattle show ancestry from multiple independent domestication events. Proc. Natl. Acad. Sci. 110(15): E1398-E1406.

Muñiz-Cruz, J.M., N. Peña-Alvarado, W. Torres-Ruiz, J.R. Almodóvar-Rivera, K.I. Domenech-Pérez, Z.E. Contreras-Correa, G.C. Muñiz-Colón, A.C. Cortés-Arocho, J.M. Santiago-Rodríguez, S. Ruiz-Ríos, G.A. Soriano-Varela, N.N. Cortés-Viruet, A.L. Jiménez-Arroyo, G.M. Jiménez-Arroyo and H.L. Sánchez Rodríguez, 2018. Sweat gland cross-sectional cut areas comparisons between slick and wild typehaired Holstein and Senepol cows in Puerto Rico. ADSA 2018. Knoxville, Tennessee. June 24-27, 2018.

Olson, T.A., C. Lucena, C.C. Chase and A.C. Hammond, 2003. Evidence of a major gene influencing hair length and heat tolerance in cattle. J. Anim. Sci. 81(1):80-90.

Rouse, J.E., 1977. The Criollo: Spanish cattle in the Americas. University of Oklahoma Press.

Sánchez, H., A. Castro, M. Pagán, J. Curbelo, A. Mesonero and G. Muñiz, 2015. Effects of the thermal humidity index on vaginal temperature of slick- and wild type-haired Puerto Rican Holstein cows. Joint Annual Meeting ADSA-ASAS 2015. Orlando, Florida. July 12-16, 2015.

Sánchez-Rodríguez, H.L., 2019. Revisión histórica y científica sobre el desarrollo de la ganadería de leche en Puerto Rico con énfasis en el ganado pelón. J. Agric. Univ. P. R. 103(1): 107-139.

Sánchez-Rodríguez, H.L., Z. Contreras-Correa, M. Pagán-Morales, J. Curbelo-Rodríguez, A. Mesonero-Morales, C. Cabrera-Cabrera and G. Muñiz-Colón, 2016. Associations between the environmental conditions and vaginal temperature in wild-type and slick-haired Puerto Rican Holstein cows. Joint Annual Meeting, ASAS-ADSACSAS-WSASAS. Salt Lake City, Utah. July 19-23, 2016.

Sánchez-Rodríguez, H.L. and K. Domenech-Pérez, 2018. Relationship between air and vaginal temperatures in wild type and slick-haired Puerto Rican Holstein cows. ADSA 2018. Knoxville, Tennessee. June 24-27, 2018.

Turner, J.W., 1980. Genetic and biological aspects of Zebu adaptability. J. Anim. Sci. 50(6): 1201-1205.

West, J.W., 2003. Effects of heat-stress on production in dairy cattle. J. Dairy Sci. 86: 2131-2144. 